\title{
Atherogenic risk pattern among Nigerian hypertensive and diabetic patients undergoing follow-up visit in a tertiary hospital
}

\author{
Bolarinwa A.O. ${ }^{1, * A h m e d ~ A . ~}{ }^{\text {; }}$ Bello A.H. ${ }^{3}$, Obalowu I.A. ${ }^{4}$, Sani M.D. ${ }^{5}$, Biliaminu S.A. ${ }^{6}$, \\ Abdulazeez I.M.
}

\begin{abstract}
Objectives: Cardiovascular risk can be predicted using lipid ratios such as the atherogenic index which is defined as the base 10 logarithm of the ratio of plasma triglyceride (TG) to high density lipoprotein cholesterol (HDL-C) - it is a useful prognostic parameter for guiding timely interventions and has also been employed as a predictor of cardiovascular risk. However, this is rarely used in the clinical practice in developing countries including Nigeria.
\end{abstract}

Methods: This study was a hospital-based cross-sectional study of 382 hypertensive and diabetic patients attending outpatient clinics of a tertiary hospital in Nigeria. Atherogenic risk profile, was categorized as low risk $(<0.1)$, intermediate risk $(0.1-0.24)$, and high risk $(>0.24)$. Predictors were established using regression analysis. Level of significance was set at $p$-value of $<0.05$ and $95 \%$ confidence interval.

Results: The mean age of participants was $56 \pm 12$ years, $31.4 \%$ of participants had high atherogenic risk. This was higher among female patients (60.0\%). Participants with high TC, high LDL, uncontrolled blood pressure had odds of $1.64,1.43$ and 1.17 times of developing high atherogenic risk respectively.

Conclusion: A significant proportion of participants in this study population were at risk of developing atherosclerosis. Key identified populations at risk of CVD should be considered for routine artherogenic assessment.

Keywords: Atherogenic, indices, hypertension, diabetes

\footnotetext{
*Correspondence author

Ahmed A.

http://orcid.org/0000-0001-6954-7459

E-mail: ahmedabdelus@yahoo.com

${ }^{1}$ Department of Epidemiology and Community Health, University of Ilorin, Nigeria.

${ }^{2}$ Department of Community Medicine and Primary Care, Federal Medical Centre, Abeokuta, Nigeria.

${ }^{3}$ Department of Internal medicine, University of Ilorin Teaching Hospital, Ilorin, Nigeria.

${ }^{4}$ Department of Family Medicine, General Hospital, Ilorin, Nigeria.

${ }^{5}$ Department of Community Medicine, Abubakar Tafawa Balewa University Teaching Hospital, Bauchi, Nigeria.

${ }^{6}$ Department of Chemical Pathology, University of Ilorin, Ilorin, Nigeria
}

Research Journal of Health Sciences subscribed to terms and conditions of Open Access publication. Articles are distributed under the terms of Creative Commons Licence (CC BY-NC-ND 4.0). (http://creativecommons.org/licences/by-nc-nd/4.0).

http://dx.doi.org/10.4314/rejhs.v6i4.7

Res. J. of Health Sci. Vol 6(4), Oct./Dec., 2018 


\title{
Profil de risque athérogénique chez les patients nigérians hypertendus et diabétiques subissant une visite de suivi dans un hôpital tertiaire
}

\author{
Bolarinwa A.O. ${ }^{1, * A h m e d ~ A . ~}{ }^{2}$; Bello A.H. ${ }^{3}$, Obalowu I.A. ${ }^{4}$, Sani M.D. ${ }^{5}$, Biliaminu S.A. ${ }^{6}$, \\ Abdulazeez I.M.
}

\section{Resume}

Objectifs: Le risque cardiovasculaire peut être prédit à l'aide des ratios lipidiques tels que l'indice athérogène, défini comme le logarithme en base 10 du ratio des triglycérides plasmatiques (TG) sur le cholestérol lié aux lipoprotéines de haute densité (HDL-C) - il s'agit d'un paramètre pronostique utile pour guidant des interventions opportunes et a également été utilisé comme facteur prédictif du risque cardiovasculaire. Cependant, cela est rarement utilisé dans la pratique clinique dans les pays en développement, y compris le Nigéria.

Méthodes: Cette étude était une étude transversale en milieu hospitalier de 382 patients hypertendus et diabétiques fréquentant des cliniques de consultation externe d'un hôpital tertiaire au Nigéria. Le profil de risque athérogène a été classé dans les catégories suivantes: risque faible $(<0,1)$, risque intermédiaire $(0,1-0,24)$ et risque élevé $(>0,24)$. Les prédicteurs ont été établis par analyse de régression. Le niveau de signification a été fixé à une valeur $\mathrm{p}$ de $<0,05$ et un intervalle de confiance à $95 \%$.

Résultats: L'âge moyen des participants était de $56 \pm 12$ ans, 31,4\% des participants avaient un risque athérogène élevé. Ce taux était plus élevé chez les patientes $(60,0 \%)$. Les participants présentant une pression artérielle élevée, un cholestérol LDL élevé et une tension artérielle non contrôlée élevée avaient respectivement des chances de développer un risque élevé de risque athérogène de 1,64, 1,43 et 1,17.

Conclusion: Une proportion significative des participants de cette population étudiée présentait un risque de développer une athérosclérose. Les populations clés identifiées à risque de MCV doivent être considérées pour une évaluation athérogénique de routine.

Mots-clés: athérogène, indices, hypertension, diabète

\author{
* Auteur de la correspondance \\ AhmedA. \\ http://orcid.org/0000-0001-6954-7459 \\ E-mail:ahmedabdelus@yahoo.com \\ ${ }^{1}$ Department of Epidemiology and Community Health, University of Ilorin, Nigeria. \\ ${ }^{2}$ Department of Community Medicine and Primary Care, Federal Medical Centre, Abeokuta, Nigeria. \\ ${ }^{3}$ Department of Internal medicine, University of Ilorin Teaching Hospital, Ilorin, Nigeria. \\ ${ }^{4}$ Department of Family Medicine, General Hospital, Ilorin, Nigeria. \\ ${ }^{5}$ Department of Community Medicine, Abubakar Tafawa Balewa University Teaching Hospital, Bauchi, Nigeria. \\ ${ }^{6}$ Department of Chemical Pathology, University of Ilorin, Ilorin, Nigeria
}




\section{INTRODUCTION}

The atherogenic index of plasma (AIP), is defined as the base 10 logarithm of the ratio of plasma triglyceride (TG) to high density lipoprotein cholesterol (HDL-C), and has been shown to be significant predictors for metabolic disturbances including dyslipidemia, atherosclerosis, hypertension and cardiovascular diseases (CVD) $(1,2)$. The term was proposed by Dobiasova and Frohlich to indicate that plasma atherogenicity was also a significant independent predictor of coronary heart disease (CHD) $(3,4)$. It has been established that an AIP value of less than 0.11 is associated with low risk of CHD; the values between 0.11 to 0.24 and greater than 0.24 are associated with intermediate and high risks, respectively $(5,6)$. Sensitivity of AIP has also been demonstrated in a cohort of patients undergoing coronary angiography, where it was found to be better than age, body mass index (BMI), waist circumference, type 2 diabetes mellitus (DM), blood pressure (BP), smoking, TG, total cholesterol (TC), low density lipoprotein (LDL-C), HDL-C, and TC/HDL-C, in predicting the possibility of positive findings $(6,7)$.

In Western populations, dyslipidemia among patients with hypertension is a common finding. The prevalence of dyslipidemia coexisting with hypertension has been estimated at $15-24 \%(8,9)$. Over $40 \%$ of all newly diagnosed hypertensive patients have at least one lipid abnormality (10). There is limited data on the burden of dyslipidemia among patients with hypertension in sub-Sahara Africa (SSA) whereas; hypertension and dyslipidemia are both identified as independent modifiable risk factors for CVD. Some studies have suggested that dyslipidemia may play a role in the development of hypertension via endothelial damage (11) and the risk for CVD is higher in the presence of both hypertension and dyslipidemia than by the individual disease entities (12). In high income countries, strategies targeting the reduction of serum cholesterol levels provide the single most important benefit against CVD resulting from coronary heart disease (CHD) (13).

Presently, medical practice encourages risk stratification for all persons at risk of CHD including those with hypertension. This is advantageous for timely intervention in preventing CHD and its' sequelae. Cardiovascular risk assessment based solely on serum low density lipoprotein cholesterol (LDLC) has been found to be inadequate $(14,15)$ and even in those on statin therapy with normal or near normal LDL-C serum levels, there remains risk for future cardiovascular events. Hypertriglyceridemia has been identified as an independent cardiovascular risk factor $(16,17)$. Hypertriglyceridemia is a proxy for atherogenic dyslipidemia (elevated triglyceride (TG)) and low high-density lipoprotein cholesterol) (17, 18), a component of the metabolic syndrome and a known risk factor for CHD. Despite interaction with other lipids that might increase atherogenic risk and in-subject variation, elevated TG has been shown to be a good predictor of CHD in consideration of the HDL-C levels (18) and is used in clinical practice to predict atherosclerosis $(18,19)$ The lipid ratio log [TG/HDL-C] (atherogenic index) provides an alternative simple option for risk stratification. The use of this ratio is to reflect the balance between risk and protective lipoprotein forces (16) as well as acting as a correlate with LDL-C particle size (20), LDL-phenotype B, and small HDL-C particles (4). This ratio has also been evaluated as a prognostic tool in predicting CHD (4) and its predictive value far outweighs that of absolute lipid parameters $(21,22)$ as well as the TC /HDL ratio (22) given its strong correlation with lipoprotein particle size.

Nigeria bears a significant burden of hypertension and like other SSA countries is not adequately equipped with the necessary resources, expertise, and technology to manage the CVD sequelae. A rural population in Uganda reflected the dominant dyslipidemia pattern to be that of low serum HDL-C levels and a good proportion with hypertriglyceridemia (23). Whereas there are well-recognized recommendations on the use of serum LDL-C and TC for cardiovascular risk assessment, there is limited progress in addressing concerns with low serum HDL-C which may lead to underestimation of CHD risk (24). Thus, assessment of atherogenic index provides a simple and reliable method for point of care risk assessment that can be done by healthcare providers even within hard-to-reach areas. The aim of this study was to assess the atherogenic risk profile using the atherogenic index among Hypertensive and Diabetic Patients in University of Ilorin Teaching Hospital.

\section{METHODS}

\section{Study design and study setting}

This was a hospital-based crosssectional study among registered patients with hypertension and diabetes attending outpatient clinics (General Outpatient Department and the 
Medical Outpatient Department) of the University of Ilorin Teaching Hospital (UITH), Ilorin, Nigeria. The hospital serves as a tertiary health facility and receives referral from public and private hospitals from within and outside the state. Adult patients (of over 18 years of age) with hypertension, or having both hypertension and diabetes were recruited into the study. Desired sample size of 382 patients was recruited using systematic random allocation over 6 months in 2016.

\section{Informed consent and Ethics}

Informed consent was obtained from eligible patients after explaining research concept to the patients in the language they best understand. Ethical approval for this study was obtained from the UITH Ethical Review Committee.

\section{Data collection and analysis}

Data was collected using Clinical Report Form (CRF) and a standardised questionnaire. The CRF was used to collect data on patients' medical information and records of parameters such as; BP, BMI, biochemical profile, disease history, drug history, complication and comorbidity history and hospital follow-up history. An interviewer-administered questionnaire was used to collect information on sociodemography.

\section{Measurement}

Physical Measurement: Blood pressure measurement, height and weight were measured as described by Riha et al (25). Participants found to have systolic blood pressure $\geq 140 \mathrm{mmHg}$ and/or diastolic pressure $\geq 90 \mathrm{mmHg}$ were referred to as having poorly controlled hypertension. Participant categorization using BMI was as follows: BMI $\leq 18.5$, "underweight," BMI 18.5-24.9, "normal weight," BMI 25-29.9, "overweight," and BMI $\geq 30$, "obese".

Laboratory Measurement: Participants underwent phlebotomy where blood samples for lipid profile (TC, TG, HDL-C, and LDLC) were collected. Blood samples were transported on the same day of collection to a central laboratory for processing and testing. Lipid profile analysis was done using the enzymatic colorimetric assay by the Cobas Integra 400 Plus C. Cut-off values for the different lipid parameters representative of dyslipidemia were as follows: $\mathrm{TC}>5.2 \mathrm{mmol} / \mathrm{L}$, $\mathrm{TG}>2.3 \mathrm{mmol} / \mathrm{L}, \mathrm{LDLC}>3.4 \mathrm{mmol} / \mathrm{L}$ and HDL$\mathrm{C}<1.04 \mathrm{mmol} / \mathrm{L}$ for male, and $<1.3 \mathrm{mmol} / \mathrm{L}$ for female. Atherogenic risk profile, was categorized as low risk $(<0.1)$, intermediate risk $(0.1-0.24)$, and high risk $(>0.24)$.

The data was analysed using IBMC SPSS version 22. A descriptive analysis of sociodemographic characteristics, biophysical, biochemical and clinical profile was done. Inferential statistics on determinants of atherogenic index risk was performed using t-test and F-tests. These formed the basis for regression analyses (simple and binary). The levels of significance were set at $95 \%$ confidence interval (95\% CI) while p-value of $<0.05$ was set to be statistically significant.

\section{RESULTS}

Table 1 shows the socio-demography and clinical profile of patients. The mean age of participants was $56 \pm 12$ years. Patients within the age group 41-60 years constituted the majority $(47.6 \%)$ of the study population while females predominate in all the age group except in those aged $\leq$ 40years with slightly lower proportion (49.0\%). Majority (74.6\%) were married and largely engaged in small business $(49.2 \%)$.

Biochemically, only $23.0 \%$ of the patients whose blood samples were analysed for TC had desirable (normal) TC $(\leq 5.2 \mathrm{mmol} / \mathrm{l})$ while majority $75.9 \%$ had high TC. However, $69.4 \%$ had desirable triglyceride, $49.5 \%$ and $78.5 \%$ had normal HDL-c and LDL respectively (Table 1).

Biophysical characteristics revealed that $3.7 \%$ of the patients were underweight with BMI $<18.5$ while over a quarter $(36.9 \%)$ were overweight. Higher proportions of female participants were found to be overweight and obese accounting for $67.4 \%$ and $87.7 \%$ respectively. Similarly, higher proportions of females $(55.7 \%)$ had uncontrolled BP than the males $(44.3 \%)$.

Atherogenic risk: More than a quarter of participants (31.4\%) had high atherogenic risk (> 0.24). Gender stratification shows that high atherogenicity was higher among female patients than males $(60.0 \%$ and $40.0 \%$ respectively). Factors associated with atherogenic risk are as shown in table 2. Participants whose ages were $\leq$ 40 years and $\geq 6$ years had higher proportions (40.8\% and $33.6 \%$ ) of high Atherogenic risk respectively, however, this association was not found to be statistically significant $(\mathrm{p}$ - value = 0.164 ). Furthermore, $28.6 \%$ of participants with high TC had intermediate Atherogenic risk, while $59.8 \%$ of those with high $\mathrm{TG}$ and $55.0 \%$ of abnormal HDL had high Atherogenic risk with varying statistical significance ( $p$-values of 
$0.048,<0.001$ and $<0.001$ respectively) However, obesity, uncontrolled BP and high serum glucose among the study subjects were found not to be statistically significant.

Tables 3 and 4 demonstrate regression analyses. Simple linear regression revealed that TG, HDL and LDL had linear relationship with high atherogenic risk as an independent entity with significance at $<0.001$. For every unit increase of atherogenic index; there was a corresponding increase in the serum level of TG by $0.540 \mathrm{mmol} / \mathrm{L}$, and $0.062 \mathrm{mmol} / \mathrm{L}$ increase for LDL. Conversely, for every decrease in a unit of atherogenic index, there was a corresponding decrease in the serum level of (abnormal) HDL by $-0.775 \mathrm{mmol} / 1$.

Predictors of high atherogenic risk on binary regression were TC, LDL, abnormal BMI (overweight and obese), uncontrolled BP and high serum glucose. Participants with high TC were 1.64 times of having high atherogenic risk, while those with high LDL, overweight, obese, uncontrolled BP and high serum glucose were $1.43,1.48,1.34,1.17$ and 1.23 times of developing high atherogenic risk respectively.

\section{DISCUSSION}

This study revealed that over threequarter of the patients being followed-up at UITH Ilorin, had hypercholesterolaemia (TC) while half of them had dyslipidaemia (low serum HDL) which was more pronounced among female patients. This implied increased risk of developing CHD and worsened medical outcome (4). Similarly, large proportion of the study participants were obese and had uncontrolled BP despite being on treatment. These indicated inadequate treatment which could be multifactorial and corroborated findings from other studies that reported medical follow-up for hypertension in Nigeria. The study has established that both weight and uncontrolled BP are independent risks for CVD and CHD (4).

About a third (31.4\%) of the participants had high atherogenic risk, of which females constituted majority $(60 \%)$. This finding is higher compared to a similar study in Uganda where only a quarter had high atherogenic risk (4). Conversely, females were more at risk in our study than that of Ugandan study where males had higher risk. Almost half (49.5\%) of the participants had uncontrolled BP with females being majority $(55.7 \%)$ and the most likely explanation could be that females constituted the majority of the study population.

Factors that showed significant association with high atherogenic risk in this study were abnormal TC, high TG and low serum level of HDL. A high serum level of TG and low serum HDL are integral of what constitute dyslipidaemia. This finding is in conformity with a population-based survey done in Iran and using the atherogenic index found a similar high estimate of atherogenic risk (27). Similarly, study involving 52 countries spread across all continents (INTERHEART study), found that persons with history of myocardial infarction had three times the odds of having atherogenic dyslipidemia compared to persons without history of myocardial infarction (28). Furthermore, an observational study done in Brazil found that persons with coronary disease had two times the odds of having an abnormal TG/HDL-C ratio (29). Although not found to be statistically significant in this study, high serum glucose level was also associated with high atherogenic risk. Diabetes affects the integrity of the vasculature and is also associated with other conditions that predispose to CHD, such as hypertension and dyslipidemia that may explain the increased risk (4).

Regression analyses revealed that the determinants of atherogenic risk were serum $\mathrm{TG}$, HDL and serum LDL with significance at $<$ 0.001. Participants with high TC were 1.64 times of having high atherogenic risk, while those with high LDL, overweight, obese, uncontrolled BP and high serum glucose were 1.43, 1.48, 1.34, 1.17 and 1.23 times of developing high atherogenic risk respectively. Previous epidemiological studies have shown that cholesterol, uncontrolled BP and serum glucose were predictors of CHD and LDL-C was associated with future risk (30); this is in tandem with our findings in this study. Similar to the Framingham and the INTERHEART studies (28, 30) obesity and overweight were associated with high atherogenic risk in this study population.

\section{CONCLUSION}

A significant proportion of participants in this study population are at risk of developing atherosclerosis. Persons with uncontrolled hypertension, dyslipidaemia and uncontrolled glycaemia, appear to be more at risk and may be considered as target groups for intervention programs. Follow-up studies are needed to further assess the risk among younger age group. Assessment of atherogenic index for all patients at risk of developing metabolic syndrome should be given due consideration by healthcare providers since it has been established to provide 
a simple and reliable method for point of care risk assessment even within hard-to-reach areas.

Conflict of Interest: None to declare

\section{REFERENCES}

1. Parinita K. Study of serum lipid profile in individuals residing in and around Nalgonda. Int $\mathrm{J}$ pharm Bio Sci. 2012; 2:110-116

2. Holmes DT, Frohlich J, Buhr KA. The concept of precision extended to the atherogenic index of plasma. ClinBiochem. 2008;41(7-8):631-5.

3. Dobiasova M, Frohlich J. The plasma parameter $\log$ (TG/HDL-C) as an atherogenic index: correlation with lipoprotein particle size and esterification rate in apoB-lipoprotein-depleted plasma (FERHDL). ClinBiochem 2001; 34: 583-8.

4. Clara W, Gershim A, Ivan K, Laban W, Steven J. $\mathrm{R}$, Rebecca N. N et al. Atherogenic Risk Assessment among Persons Living in Rural Uganda Hindawi Publishing Corporation Journal of Tropical Medicine Volume 2016, Article ID $7073894, \quad 8 \quad$ p a g e s http://dx.doi.org/10.1155/2016/7073894

5. Dobiásová M, Frohlich J, Sedová M, Cheung MC, Brown BG. Cholesterol esterification and atherogenic index of plasma correlate with lipoprotein size and findings on coronary angiography.J Lipid Res. 201; 52(3):566-71.

6. Dobiásová M. AIP--atherogenic index of plasma as a significant predictor of cardiovascular risk: from research to practice.VnitrLek.2006; 52(1):64-71

7. Grover SA, Levington C, Paquet S. Identifying adults who are at a low risk for significant hyperlipidemia: a validated clinical index. J ClinEpidemiol 1999; 52: 49-55.

8. J. J. Dalal, T. N. Padmanabhan, P. Jain, S. Patil, H. Vasnawala, and A.Gulati, "Lipitension: Interplay between dyslipidemia and hypertension," Indian Journal of Endocrinology andMetabolism, vol. 16, no. 2, pp. 240-245, 2012.

9. W. B.Kannel, "Fifty years of Framingham study contributions to understanding hypertension," Journal of Human Hypertension, vol. 14, no. 2, pp. 83-90, 2000.

10. A. Bottger, H. A. Van Lith, V. Kren et al., "Quantitative trait loci influencing cholesterol and phospholipid phenotypes map to chromosomes that contain genes regulating blood pressure in the spontaneously hypertensive rat," Journal of Clinical Investigation, vol. 98, no. 3, pp. 856-862, 1996.

11. F. Thomas, K. Bean, L. Guize, S. Quentzel, P. Argyriadis, and A. Benetos, "Combined effects of systolic blood pressure and serum cholesterol on cardiovascular mortality in young ( $<$ years) men and women," European Heart Journal, vol. 23, no. 7, pp. 528-535, 2002.

12. P.Castelli andK. Anderson, "Apopulation at risk: prevalence of high cholesterol levels in hypertensive patients in the Framinghamstudy," The American Journal ofMedicine, vol. 80, no. 2, pp. 33-39, 1986.

13. P. W. F. Wilson, R. B. D'Agostino, D. Levy, A. M. Belanger, H. Silbershatz, and W. B. Kannel, "Prediction of coronary heart disease using risk factor categories," Circulation, vol. 97, pp.1837-1847, 1998 .

14. J. Mill'an, X. Pint'o, A. Mũnoz et al., "Lipoprotein ratios: physiological significance and clinical usefulness in cardiovascular prevention," Vascular Health and Risk Management, vol. 5, pp. 757-765, 2009.

15. H. R. Superko and S. King, "Lipid management to reduce cardiovascular risk: a new strategy is required," Circulation, vol. 117, pp. 560-568, 2008.

16. M. Dobi'a`sov'a, "Atherogenic index of plasma [log(triglycerides/HDL-cholesterol)]: theoretical and practical implications," Clinical Chemistry, vol. 50, no. 7, pp. 1113-1115, 2004.

17. V. Bittner, B. D. Johnson, I. Zineh et al., "The triglyceride/highdensity lipoprotein cholesterol ratio predicts all-causemortality in women with suspected myocardial ischemia. A Report From the Women's Ischemia Syndrome Evaluation (WISE)," American Heart Journal, vol. 157, no. 3, pp. 548-555, 2009.

18. J. M. Gaziano, C. H. Hennekens, C. J. O'Donnell, J. L. Breslow, and J. E. Buring, "Fasting triglycerides, high-density lipoprotein, and risk of myocardial infarction," Circulation, vol. 96, no. 8, pp. 2520-2525, 1997.

19. U. Nwagha, E. J. Ikekpeazu, F. E. Ejezie, E. E. Neboh, and I. C. Maduka, "Atherogenic index of plasma as useful predictor of cardiovascular risk among postmenopausal women in Enugu, Nigeria," African Health Sciences, vol. 10, no. 3, pp. 248-252, 2010.

20. K. Wan, J. Zhao, H. Huang et al., "The association between triglyceride/high-density lipoprotein cholesterol ratio and all cause mortality in acute coronary syndrome after coronary revascularization," PLoS ONE, vol. 10,no. 4, Article IDe0123521, 2015.

21. W. P. Castelli, "Epidemiology of coronary heart disease: The Framingham Study," The American Journal of Medicine, vol. 76, no. 2, pp. 4-12, 1984.

22. M. Dobi'a`sov'a, "AIP — atherogenic index of plasma as a significant predictor of cardiovascular risk: fromresearch to practice," Vnitrni Lekarstvi, vol. 52, no. 1, pp. 64-71, 2006.

23. G. Asiki, G. A. V. Murphy, K. Baisley et al., "Prevalence of dyslipidaemia and associated risk factors in a rural population in SouthWesternUganda: a community based survey," PLoSONE, vol. 10, no. 5, Article ID e0126166, 2015.

24. G. F. Watts, "Treating patients with low HDLcholesterol: choices, issues and opportunities," 
Current Controlled Trials inCardiovascular Medicine, vol. 2, no. 3, pp. 118-122, 2001.

25. J.Riha, A. Karabarinde, G. Ssenyomo et al., "Urbanicity andlifestyle risk factors for cardiometabolic diseases in rural Uganda: a crosssectional study," PLoS Medicine, vol. 11, no. 7, Article ID e1001683, 2014.

26. J. Idemudia, E. Ugwuja, O. Afonja, E. Idogun, and N. Ugwu, "CReactive proteins and cardiovascular risk indices in hypertensivNigerians," The Internet Journal of Cardiovascular Research, vol. 6, no. 2, 2008

27. S. Niroumand, M. Khajedaluee, M. KhademRezaiyan et al., Atherogenic Index of Plasma (AIP): a marker of cardiovascular disease, "Medical Journal of The Islamic Republic of Iran
(MJIRI), vol. 29, p. 240, 2015.

28. S. Yusuf, S. Hawken, S. ^ Ounpuu et al., "Effect of potentially modifiable risk factors associated with myocardial infarction in 52 countries (the INTERHEART study): case-control study," The Lancet, vol. 364, no. 9438, pp. 937-952, 2004.

29. P. L. Da Luz, D. Favarato, J. R. Faria-Neto Jr., P. Lemos, and A. C. P. Chagas, "High ratio of triglycerides to HDL-cholesterol predicts extensive coronary disease," Clinics, vol. 63, no. 4, pp. 427-432, 2008.

30. C. J. O'Donnell and R. Elosua, "Cardiovascular risk factors. Insights from framingham heart study," Revista Espa nola de Cardiolog'1a, vol. 61, no. 3, pp. 299-310, 2008. 
Table 1: Sociodemographic, clinical, physical, and biochemical characteristics of Patients by gender.

\begin{tabular}{|c|c|c|c|c|c|}
\hline \multirow{2}{*}{$\begin{array}{l}\text { Variables } \\
\text { Demographic }\end{array}$} & \multirow[t]{2}{*}{ All participants (\%) } & \multicolumn{2}{|c|}{ Gender } & \multirow[t]{2}{*}{$\chi^{2}$} & \multirow[t]{2}{*}{$\mathbf{P}$} \\
\hline & & Male (\%) & Female $(\%)$ & & \\
\hline \multicolumn{6}{|l|}{ "Age Group } \\
\hline$=40$ & $66(17.3)$ & $34(51.0)$ & $32(49.0)$ & & \\
\hline $41-60$ & $182(47.6)$ & $55(30.2)$ & $127(69.8)$ & & \\
\hline$=61$ & $134(35.1)$ & $52(38.8)$ & $82(61.2)$ & 7.875 & 0.019 \\
\hline \multicolumn{6}{|l|}{ Level of Education } \\
\hline Primary & $69(18.1)$ & $29(40.6)$ & $41(59.4)$ & & \\
\hline Secondary & $73(19.1)$ & $36(49.3)$ & $37(50.7)$ & & \\
\hline Quranic & $9(2.4)$ & $2(22.2)$ & $7(77.8)$ & & \\
\hline Tertiary & $104(27.2)$ & $57(54.8)$ & $47(45.2)$ & & \\
\hline Vocational training & $9(2.4)$ & $5(55.6)$ & $4(44.4)$ & & \\
\hline No formal education & $118(30.9)$ & $7(5.9)$ & $111(94.1)$ & 71.263 & $<0.001$ \\
\hline \multicolumn{6}{|l|}{ Marital Status } \\
\hline Married & $285(74.6)$ & $121(42.5)$ & $164(57.5)$ & & \\
\hline Single & $5(1.3)$ & $4(80.0)$ & $1(20.0)$ & & \\
\hline Divorced & $8(2.1)$ & $4(50.0)$ & $4(50.0)$ & & \\
\hline Widowed & $84(22.0)$ & $6(7.1)$ & $78(92.9)$ & 40.660 & $<0.001$ \\
\hline \multicolumn{6}{|l|}{ Occupation } \\
\hline Small business & $188(49.2)$ & $44(23.4)$ & $144(76.6)$ & & \\
\hline Large business & $22(5.8)$ & $8(36.4)$ & $14(63.6)$ & & \\
\hline Civil servant & $116(30.4)$ & $51(44.0)$ & $65(56.0)$ & & \\
\hline Unemployed & $55(14.4)$ & $32(58.2)$ & $23(41.8)$ & 28.031 & $<0.001$ \\
\hline \multicolumn{6}{|l|}{$\begin{array}{l}\text { Biochemical } \\
\text { characteristics }\end{array}$} \\
\hline \multicolumn{6}{|l|}{ Total cholesterol } \\
\hline Desirable $(=5.2 \mathrm{mmol} / \mathrm{l})$ & $88(23.0)$ & $32(36.4)$ & $56(63.6)$ & & \\
\hline $\operatorname{High}(>5.2 \mathrm{mmol} / \mathrm{l})$ & $290(75.9)$ & $102(35.2)$ & $188(64.8)$ & 0.042 & 0.838 \\
\hline \multicolumn{6}{|l|}{ Triglyceride } \\
\hline Desirable $(=2.3 \mathrm{mmol} / \mathrm{L})$ & $265(69.4)$ & $93(35.1)$ & $172(64.9)$ & & \\
\hline $\operatorname{High}(>2.3 \mathrm{mmol} / \mathrm{L})$ & $117(30.6)$ & $42(35.9)$ & $75(64.1)$ & 0.023 & 0.880 \\
\hline \multicolumn{6}{|l|}{ HDL-C } \\
\hline $\begin{array}{l}\text { Abnormal (<1.04-m, 1.3-f), } \\
\text { low }\end{array}$ & $191(50.0)$ & $76(39.8)$ & $115(60.2)$ & & \\
\hline Normal (=1.04-m, 1.3-f) & $189(49.5)$ & $57(30.2)$ & $132(69.8)$ & 3.874 & 0.049 \\
\hline \multicolumn{6}{|l|}{ LDL-C } \\
\hline Normal $(=3.4 \mathrm{mmol} / \mathrm{L})$ & $300(78.5)$ & $110(36.7)$ & $190(63.3)$ & & \\
\hline $\operatorname{High}(>3.4 \mathrm{mmol} / \mathrm{L})$ & $82(21.5)$ & $25(30.5)$ & $57(69.5)$ & 1.076 & 0.300 \\
\hline \multicolumn{6}{|l|}{ Serum glucose } \\
\hline Normal $(<11 \mathrm{mmol} / \mathrm{L})$ & $340(89.0)$ & $119(35.0)$ & $221(65.0)$ & & \\
\hline $\operatorname{High}(=11 \mathrm{mmol} / \mathrm{L})$ & $36(9.4)$ & $14(38.9)$ & $22(61.1)$ & 0.215 & 0.643 \\
\hline \multicolumn{6}{|l|}{ Biophysical characteristic } \\
\hline \multicolumn{6}{|l|}{ BMI } \\
\hline Underweight $(<18.5)$ & $14(3.7)$ & $7(50.0)$ & $7(50.0)$ & & \\
\hline Normal (18.5-24.9) & $118(30.9)$ & $67(56.8)$ & $51(43.2)$ & & \\
\hline Overweight $(=25)$ & $141(36.9)$ & $46(32.6)$ & $95(67.4)$ & & \\
\hline Obese & $106(27.7)$ & $13(12.3)$ & $93(87.7)$ & 50.361 & $<0.001$ \\
\hline \multicolumn{6}{|l|}{ Clinicalcharacteristics } \\
\hline \multicolumn{6}{|l|}{ Blood Pressure } \\
\hline $\begin{array}{l}\text { Controlled }(<140 / 90 \\
\mathrm{mmHg})\end{array}$ & $233(61.0)$ & $69(29.6)$ & $164(70.4)$ & & \\
\hline $\begin{array}{l}\text { Uncontrolled }(=140 / 90 \\
\mathrm{mmHg})\end{array}$ & $189(49.5)$ & $66(44.3)$ & $83(55.7)$ & 8.573 & 0.003 \\
\hline \multicolumn{6}{|l|}{ Atherogenic risk } \\
\hline Low $(<0.1)$ & $262(68.6)$ & $87(33.2)$ & $175(66.8)$ & & \\
\hline $\operatorname{High}(>0.24)$ & $120(31.4)$ & $48(40.0)$ & $72(60.0)$ & 1.662 & 0.197 \\
\hline
\end{tabular}

${ }^{*}$ Mean $\pm \mathrm{SD}=56 \pm 12 \mathrm{yrs}$ 
Table 2: factors associated with Atherogenic risk among patients

\begin{tabular}{|c|c|c|c|c|}
\hline \multirow{2}{*}{$\begin{array}{l}\text { Variables } \\
\text { Demographic } \\
\end{array}$} & \multicolumn{2}{|c|}{ Antherogenic } & \multirow[t]{2}{*}{$\chi^{2}$} & \multirow[t]{2}{*}{$\mathbf{P}$} \\
\hline & Low (\%) & High (\%) & & \\
\hline \multicolumn{5}{|l|}{ Age Group } \\
\hline$=40$ & $29(59.2)$ & $20(40.8)$ & & \\
\hline $41-60$ & $144(72.4)$ & $55(27.6)$ & & \\
\hline$=61$ & $89(66.4)$ & $45(33.6)$ & 3.620 & 0.164 \\
\hline \multicolumn{5}{|l|}{ Gender } \\
\hline Male & $87(64.4)$ & $48(35.6)$ & & \\
\hline Female & $175(70.9)$ & $72(29.2)$ & 1.662 & 0.197 \\
\hline \multicolumn{5}{|c|}{ Biochemical characteristics } \\
\hline \multicolumn{5}{|c|}{ Total cholesterol } \\
\hline Normal & $53(60.2)$ & $35(39.8)$ & & \\
\hline Abnormal & $207(71.4)$ & $83(28.6)$ & 3.910 & 0.048 \\
\hline \multicolumn{5}{|l|}{ Triglyceride } \\
\hline Normal & $215(81.1)$ & $50(18.9)$ & & \\
\hline Abnormal & $47(40.2)$ & $70(59.8)$ & 63.206 & $<0.001$ \\
\hline \multicolumn{5}{|l|}{ HDL-C } \\
\hline Abnormal & $86(45.0)$ & $105(55.0)$ & & \\
\hline Normal & $174(92.1)$ & $15(7.9)$ & 97.277 & $<0.001$ \\
\hline \multicolumn{5}{|l|}{ LDL-C } \\
\hline Normal & $201(67.0)$ & $99(33.0)$ & & \\
\hline Abnormal & $61(74.4)$ & $21(25.6)$ & 1.632 & 0.201 \\
\hline \multicolumn{5}{|l|}{ Serum glucose } \\
\hline Normal & $233(68.5)$ & $107(31.5)$ & & \\
\hline High & $23(63.9)$ & $13(36.1)$ & 0.323 & 0.570 \\
\hline \multicolumn{5}{|l|}{ BMI } \\
\hline Underweight & $10(71.4)$ & $4(28.6)$ & & \\
\hline Normal & $77(65.3)$ & $41(34.7)$ & & \\
\hline Overweight & $95(67.4)$ & $46(32.6)$ & & \\
\hline Obese & $78(73.6)$ & $28(26.4)$ & 1.986 & 0.575 \\
\hline \multicolumn{5}{|l|}{ Blood Pressure } \\
\hline $\begin{array}{l}\text { Controlled }(<140 / 90 \\
\mathrm{mmHg})\end{array}$ & $163(70.0)$ & $70(30.0)$ & & \\
\hline $\begin{array}{l}\text { Uncontrolled }(=140 / 90 \\
\mathrm{mmHg})\end{array}$ & $99(66.4)$ & $50(33.6)$ & 0.521 & 0.470 \\
\hline
\end{tabular}

Table 3: Simple Linear Regression of predictors of atherogenic risk

\begin{tabular}{|c|c|c|c|c|c|}
\hline \multirow[b]{2}{*}{ Variables } & \multirow{2}{*}{$\begin{array}{c}\text { Standardized } \\
\text { Coefficients } \\
\text { Beta }(\beta)\end{array}$} & \multirow[b]{2}{*}{$\mathbf{t}$} & \multirow[b]{2}{*}{ Sig. } & \multicolumn{2}{|c|}{$\begin{array}{l}95.0 \% \text { Confidence } \\
\text { Interval for B }\end{array}$} \\
\hline & & & & $\begin{array}{l}\text { Lower } \\
\text { Bound }\end{array}$ & $\begin{array}{l}\text { Upper } \\
\text { Bound }\end{array}$ \\
\hline Total Cholesterol (TC) & -0.072 & -1.395 & 0.164 & -0.026 & 0.004 \\
\hline Trigliceride (TG) & 0.540 & 12.514 & $<0.001$ & 0.150 & 0.206 \\
\hline HDL (abnormal) & -0.775 & -23.919 & $<0.001$ & -0.309 & -0.262 \\
\hline LDL & 0.062 & 3.612 & $<\mathbf{0 . 0 0 1}$ & 0.006 & 0.019 \\
\hline Serum Glucose & -0.003 & -0.571 & 0.568 & -0.008 & 0.004 \\
\hline BMI & -0.004 & -0.280 & 0.780 & 0.000 & 0.000 \\
\hline Average Systolic Dominant & 0.036 & 0.708 & 0.480 & -0.001 & 0.001 \\
\hline Average Diastolic Dominant & 0.049 & 0.962 & 0.337 & -0.001 & 0.002 \\
\hline Age & -0.024 & -1.647 & 0.100 & -0.001 & 0.000 \\
\hline
\end{tabular}


Table 4: Binary regression analysis of high atherogenic risk of patients

\begin{tabular}{|c|c|c|c|c|c|}
\hline \multirow[b]{2}{*}{ Variables } & \multirow[b]{2}{*}{ B } & \multirow[b]{2}{*}{$\mathbf{P}$} & \multirow[b]{2}{*}{ Odd Ratio } & \multicolumn{2}{|c|}{ 95\% C.I } \\
\hline & & & & Lower & Upper \\
\hline \multicolumn{6}{|l|}{ Age } \\
\hline$>60(\mathrm{RC})$ & & .168 & & & \\
\hline$=40$ & -0.599 & 0.073 & 0.549 & 0.285 & 1.059 \\
\hline $41-60$ & -0.310 & 0.366 & 0.733 & 0.374 & 1.437 \\
\hline \multicolumn{6}{|l|}{ Cholesterol } \\
\hline $\begin{array}{l}\text { Total cholesterol } \\
\text { (high) }\end{array}$ & 0.499 & 0.049 & 1.647 & 1.002 & 2.707 \\
\hline Triglyceride (high) & -1.857 & $<0.001$ & 0.156 & 0.097 & 0.253 \\
\hline HDL (abnormal) & -2.651 & $<0.001$ & 0.071 & 0.039 & 0.129 \\
\hline LDL (high) & 0.358 & 0.203 & 1.431 & 0.824 & 2.483 \\
\hline \multicolumn{6}{|l|}{ BMI } \\
\hline \multicolumn{6}{|l|}{ Underweight (RC) } \\
\hline Normal & 0.108 & 0.864 & 1.114 & 0.323 & 3.840 \\
\hline Overweight & 0.394 & 0.179 & 1.483 & 0.835 & 2.635 \\
\hline Obese & 0.299 & 0.292 & 1.349 & 0.773 & 2.355 \\
\hline \multicolumn{6}{|l|}{ Blood pressure } \\
\hline \multicolumn{6}{|l|}{ Controlled (RC) } \\
\hline Uncontrolled & 0.162 & 0.471 & 1.176 & 0.757 & 1.827 \\
\hline \multicolumn{6}{|l|}{ Serum glucose } \\
\hline Serum glucose (high) & 0.208 & 0.571 & 1.231 & 0.601 & 2.522 \\
\hline
\end{tabular}

